\author{
Т. А. Цувіна \\ кандидат юридичних наук, \\ доцент кафедри цивільного процесу \\ Національного юридичного університету ілені Ярослава Мудрого
}

\title{
ІНСТИТУТ КОНСТИТУЦІЙНОЇ СКАРГИ ТА ПЕРЕГЛЯД СУДОВИХ РІШЕНЬ ЗА ВИКЛЮЧНИМИ ОБСТАВИНАМИ В КОНТЕКСТІ ПРИНЦИПУ ВЕРХОВЕНСТВА ПРАВА
}

Конституційна реформа у сфері правосуддя 2016 р. заклала підвалини для реформування процесуального законодавства, що мало своїм наслідком ухвалення у 2017 р. нової редакції Цивільного процесуального кодексу України (далі - ЦПК), Господарського процесуального кодексу України (далі - ГПК) та Кодексу адміністративного судочинства України (далі - KAC). Зазначені нормативно-правові акти містять суттєві зміни щодо процесуального порядку розгляду правових спорів, диверсифікації проваджень і процедур, спрощення порядку здійснення судочинства тощо. 3 такого погляду на особливу увагу заслуговує введення такого виду перегляду, як перегляд за виключними обставинами, що вперше відбитий у рамках процесуальних кодексів. Так, відповідно до ч. 3 ст. 423 ЦПК, підставами для перегляду судових рішень у зв'язку із виключними обставинами є: 1) встановлена Конституційним Судом України неконституційність (конституційність) закону, іншого правового акта чи їхнього окремого положення, застосованого (не застосованого) судом під час вирішення справи, якщо рішення суду ще не виконане; 2) встановлення міжнародною судовою установою, юрисдикція якої визнана Україною, порушення Україною міжнародних зобов'язань під час вирішення цієї справи судом; 3) встановлення вироком суду, що набрав чинності, вини судді у вчиненні злочину, унаслідок якого ухвалено судове рішення.

Варто зазначити, що наведені підстави для перегляду судових рішень за попередньої редакції ЦПК уважалися підставами для перегляду судових рішень за нововиявленими обставинами, проте нині ці два види перегляду - перегляд за нововиявленими обставинами та перегляд за виключними обставинами - сформульовані в тексті процесуальних кодексів як окремі види перегляду судових рішень, що набрали чинності. Водночас, якщо підстави для перегляду рішень за нововиявленими обставинами нині загалом стосуються специфічних вад доказової діяльності, які були виявлені вже після розгляду справи (ч. 2 ст. 423 ЦПК), то підстави для перегляду за виключними обставинами (ч. 3 ст. 423 ЦПК) охоплюють випадки встановлення іншими судовими установами певних обставин (зокрема, неконституційності закону, порушення Україною міжнародних зобов'я- зань під час вирішення справи тощо), що мали ключове значення для провадження та ставлять під сумнів правосудність того чи іншого судового рішення.

У літературі проблемам перегляду судових рішень за нововиявленими та виключними обставинами приділялася увага таких учених, як: В.В. Комаров, Д.Д. Луспеник, Г.В. Мудрецька, Н.Ю. Сакара й ін. Водночас питанню перегляду судових рішень за виключними обставинами у зв'язку із встановленням Конституційним Судом України неконституційності закону, іншого правового акта чи їхнього окремого положення, застосованого судом під час вирішення справи, на сторінках наукової літератури увага не приділялася, хоча нині зазначене питання набуває особливої актуальності у зв'язку із введенням інституту конституційної скарги та відсутністю єдності судової практики щодо зазначеного виду перегляду.

Мета статті - зробити аналіз проблемних питань правозастосування, що виникають під час перегляду судових рішень за виключними обставинами у цивільному судочинстві з підстав визнання неконституційними положень нормативно-правових актів, крізь призму принципу верховенства права та міжнародних стандартів справедливого судочинства.

Перегляд за виключними обставинами та ретроспективна дія рішень Конституиійного Суду України. Порядок організації та діяльності Конституційного Суду України, порядок конституційного провадження, процедура розгляду справ та виконання рішень і висновків Конституційного Суду України регулюються Законом України «Про Конституційний Суд України» від 13 липня 2017 p. № 2136-VIII (далі - Закон). Так, відповідно до ст. 7 цього Закону, до повноважень Конституційного Суду України, серед іншого, належить вирішення питань про відповідність Конституції України (конституційність) законів України й інших правових актів Верховної Ради України, актів Президента України, актів Кабінету Міністрів України, правових актів Верховної Ради Автономної Республіки Крим (п. 1 ч. 1 ст. 7 Закону), а також вирішення питань про відповідність Конституції України (конституційність) законів України (їхніх окремих положень) за конституційною скаргою особи, яка вважає, що застосо- 
ваний в остаточному судовому рішенні в її справі закон України суперечить Конституції України (п. 9 ч. 1 ст. 7 Закону). За результатами розгляду справ щодо конституційності відповідних нормативно-правових актів Конституційний Суд України ухвалює рішення іменем України, яке є остаточним і не може бути оскарженим (ч. 1 ст. 84, ч. ч. 1,5 ст. 88 Закону). Порядок втрати чинності положеннями нормативного акта в разі визнання його неконституційним рішенням Конституційного Суду України врегульований ч. 2 ст. 152 Конституції України та ст. 91 Закону, відповідно до яких закони, інші акти або їхні окремі положення, що визнані неконституційними, втрачають чинність із дня ухвалення Конституційним Судом України рішення про їхню неконституційність, якщо інше не встановлено самим рішенням, але не раніше дня його ухвалення.

Водночас гл. 3 р. V ЦПК регулює процедуру перегляду судових рішень за нововиявленими або виключними обставинами. Відповідно до ч. 1 ст. 423 ЦПК, рішення, постанова або ухвала суду, якими закінчено розгляд справи, що набрали чинності, можуть бути переглянуті за нововиявленими або виключними обставинами. Відповідно до п. 1 ч. 3 ст. 423 ЦПК, однією з підстав для перегляду судових рішень у зв'язку з виключними обставинами є встановлена Конституційним Судом України неконституційність (конституційність) закону, іншого правового акта чи їхнього окремого положення, застосованого (не застосованого) судом під час вирішення справи, якщо рішення суду ще не виконане.

Системне тлумачення норм процесуального законодавства дає підстави зробити декілька висновків.

По-перше, норми ЦПК прямо передбачають можливість перегляду справи у зв'язку з визнанням неконституційності закону загалом або окремих його положень, що застосовано судом під час вирішення справи, якщо рішення суду ще не виконане. Водночас особа може подати заяву про перегляд рішення за виключними обставинами 3 підстави, передбаченої п. 1 ч. 3 ст. 423 ЦПК, якщо нормативно-правовий акт або його окремі положення визнані неконституційними як за конституційною скаргою цієї особи, так і за конституційною скаргою інших осіб, або за конституційним поданням відповідних суб'єктів. Головним є той факт, що закон або його окремі положення, що визнані неконституційними, застосовувалися судом у справі заявника, і судове рішення не було виконане.

По-друге, зміст ч. 1 та п. 1 ч. 3 ст. 423 ЦПК свідчить про певну послідовність провадження в суді загальної юрисдикції та конституційного провадження для можливості перегляду справи за виключним обставинами. Зважаючи на те, що провадження за виключними обставинами - це різновид перегляду судових рішень, якими закінчено розгляд справи, що набрали чинності (ч. 1 ст. 423 ЦПК), то конституційне провадження, за результатами якого закон визнається неконституційним, завжди має місце після провадження в суді загальної юрисдикції. Якщо ж Конституційний Суд України розглядає питання про конституційність закону під час розгляду справи в порядку цивільного судочинства, то суд зупиняє провадження на підставі п. 6 ч. 1 ст. 251 ЦПК через об'єктивну неможливість розгляду цієї справи до вирішення іншої справи, що розглядається в порядку конституційного провадження, адміністративного, цивільного, господарського чи кримінального судочинства, до набрання законної сили судовим рішенням в іншій справі. Після ухвалення рішення Конституційним Судом України справа розглядається судом загальної юрисдикції з урахуванням такого рішення.

Зазначене свідчить про те, що ухвалення рішення суду в порядку цивільного судочинства, про перегляд якого за виключними обставинами просить заявник, завжди передує ухваленню рішення Конституційним Судом України щодо неконституційності закону. Зазначимо, що незважаючи на те, що втрата чинності положеннями нормативного акта в разі визнання його неконституційним відповідно до ч. 2 ст. 152 Конституції України та ст. 91 Закону України «Про Конституційний Суд України" визначається днем ухвалення відповідного рішення Конституційним Судом України (якщо інше не встановлено самим рішенням, але не раніше дня його ухвалення), це не свідчить про те, що таке рішення не може бути підставою для перегляду за виключними обставинами судових рішень, ухвалених раніше ухвалення відповідного рішення Конституційного Суду України. Протилежне тлумачення призводило б до неможливості застосування зазначеної підстави для перегляду за виключними обставинами, адже на момент розгляду справи судом загальної юрисдикції застосовні положення законодавства завжди є чинними та конституційними, адже ще не стали предметом перевірки на конституційність у Конституційному Суді України.

Аналіз практики Касаційного цивільного суду дає підстави говорити про наявність справ, у яких перегляд справи за виключними обставинами здійснювався після визнання положень закону неконституційними, незважаючи на аргументи щодо неможливості надання рішенням Конституційного Суду України зворотної сили. Так, постановою Верховного Суду у складі колегії суддів Першої судової палати Касаційного цивільного суду від 13 листопада 2019 р. було переглянуто за виключними обставинами постанову цього ж суду від 3 жовтня 2018 р. на під- 
ставі того, що рішенням Другого сенату Конституційного Суду України від 4 вересня 2019 р. № 6-p(II)/2019 у справі № 3-425/2018(6960/18) за конституційною скаргою ОСОБА_1 щодо відповідності Конституції України (конституційності) положень ч. 3 ст. 40 Кодексу законів про працю визнано такими, що не відповідають Конституції України (є конституційними), положення ч. 3 ст. 40 Кодексу законів про працю[1].

3 огляду на зазначене, уважаємо помилковими аргументи тих судів, які відмовляють у перегляді справи за виключними обставинами з тих підстав, що на момент розгляду справи в суді норми застосовного закону ще не були визнані неконституційними. Такі приклади можна знайти, зокрема, у рішеннях, ухвалених в порядку господарського судочинства. Так, в ухвалі Східного апеляційного господарського суду від 8 серпня 2019 р. відмова в перегляді рішення за виключними обставинами обгрунтовується так: «П. 13 ч. 1 ст. 17 Закону України «Про Національне антикорупційне бюро України» втратив чинність із 5 червня 2019 р. Тому саме з 5 червня 2019 р. у НАБУ відсутнє право на подання до суду позовів про визнання недійсними угод у порядку, встановленому законодавством України. Разом з тим, у період до 5 червня 2019 р. п. 13 ч. 1 ст. 17 Закону України «Про Національне антикорупційне бюро України» підлягав застосуванню, оскільки був чинним <... $>$. Позов у цій судовій справі Національним бюро було подано 27 грудня 2016 р. на підставі чинного на той момент п. 13 ч. 1 ст. 17 Закону України «Про Національне антикорупційне бюро України», тобто в межах компетенції та у порядку, встановленому чинним законодавством України» [2]. Суперечливою також варто визнати і позицію Верховного Суду, висловлену в постанові від 20 червня 2019 р. у справі № 910/4473/17 за результатами касаційного провадження, де останній зазначив: «П. 13 ч. 1 ст. 17 Закону України «Про Національне антикорупційне бюро України» від 14 жовтня 2014 р. № 1698-V втратив чинність лише з 5 червня 2019 р., а до того мав юридичну силу, при цьому позов у даній справі Національним антикорупційним бюро України подано 21 березня 2017 р.» [3]. На підставі зазначеного Верховний Суд продовжив розгляд касаційної скарги, незважаючи на те, що фактично Конституційним Судом України було визнано відсутність повноважень Національного антикорупційного бюро України звертатися до суду в цій справі, отже, позов мав бути залишений без розгляду.

Таке тлумачення норм національного законодавства дозволяє зробити висновок, що коли рішення про неконституційність закону ухвалене за конституційною скаргою конкретної особи, то в подальшому навіть така особа не зможе звернутися до суду із заявою про перегляд рішення за виключними обставинами в її справі, адже на момент розгляду справи така норма вважалася конституційною. Проте така ситуація призводить до абсолютного нівелювання призначення інституту конституційної скарги та процесуальних гарантій права на справедливий судовий розгляд для такої особи за результатами перегляду справи за виключними обставинами.

Відповідно до ст. $151^{1}$ Конституції України, Конституційний Суд України вирішує питання про відповідність Конституції України (конституційність) закону України за конституційною скаргою особи, яка вважає, що застосований в остаточному судовому рішенні в її справі закон України суперечить Конституції України. Конституційна скарга може бути подана в разі, якщо всі інші національні засоби юридичного захисту вичерпано. Із зазначеного випливає, що конституційна скарга визнається останнім засобом правового захисту на рівні національного правопорядку. Проте за результатами розгляду такої скарги Конституційний Суд України не скасовує судові рішення у справі особи, яка подає конституційну скаргу: захист права вимагає подальшого перегляду справи за виключними обставинами, порядок якого закріплений у процесуальних кодексах. Інакше кажучи, коли за результатами розгляду конституційної скарги особи встановлена неконституційність закону, наступним кроком такої особи має бути звернення до суду, який ухвалив остаточне рішення у справі, із заявою про перегляд за виключними обставинами, і саме за результатами такого перегляду суд, який ухвалив остаточне рішення, має забезпечити відновлення прав такої особи. Якщо ж застосувати логіку Верховного Суду, то особа, яка звертається до Конституційного Суду України 3 конституційною скаргою, має задовольнятися тим фактом, що закон буде визнаний неконституційним на майбутнє, проте це жодним чином не зможе вплинути на провадження в їі справі, адже на момент розгляду справи в суді загальної юрисдикції цей закон вважався конституційним. Уважаємо, що зазначений підхід суперечить сутності та значенню конституційної скарги в механізмі захисту оспорюваних, порушених i невизнаних прав, свобод та інтересів осіб, а також призводить до неможливості застосування відповідних положень цивільного процесуального законодавства на практиці, роблячи перегляд за виключними обставинами з підстави, передбаченої в п. 1 ч. 3 ст. 423 ЦПК, ілюзорним.

Зважаючи на зазначене, на наш погляд, процесуальне законодавство прямо передбачає можливість перегляду судових рішень за виключними обставинами саме після ухвалення рішення Конституційного Суду України щодо неконституційності закону (окремих його положень), який був 
застосований у справі, що має на меті забезпечення реального, а не ілюзорного механізму захисту прав та інтересів учасників справи, що, однак, не суперечить загальному правилу про момент втрати чинності положеннями нормативного акта в разі визнання його неконституційним рішенням Конституційного Суду України.

Перегляд за виключними обставинами судових рішень за позовали про визнання. Ще одним проблемним питанням у контексті реалізації п. 1 ч. 3 ст. 423 ЦПК є можливість перегляду за виключними обставинами лише тих рішень, що не були виконані. Зазначене законодавче положення призвело до того, що суди інколи відмовляють у перегляді судових рішень за виключними обставинами, якщо судове рішення було ухвалене за позовом про визнання, наприклад, рішень за позовами про визнання договору недійсним, аргументуючи свою позицію тим, що зазначені рішення взагалі не можуть бути виконані [3]. На наш погляд, зазначений підхід має бути оцінений критично, адже він прямо суперечить нормам чинного процесуального законодавства, яке не встановлює обмежень щодо можливості такого перегляду судових рішень, що не підлягають примусовому виконанню.

У теорії процесуального права класичним є поділ позовів на види, залежно від змісту вимог, що в них містяться, відповідно до чого розрізняють позови про присудження, позови про визнання та перетворювальні позови [4, с. 520-521]. Похідною від класифікації позовів за змістовною ознакою є також класифікація судових рішень залежно від того, у справі за яким позовом вони ухвалені, на: а) рішення у справах за позовами про присудження; б) рішення у справах за позовами про визнання; в) рішення у справах за позовами про перетворення.

У контексті проблематики, що розглядається, нас передусім цікавить сутність позовів про присудження та позовів про визнання, а також природа рішень, ухвалених за результатами розгляду відповідних позовів. Так, позови про присудження - найбільш поширений вид позовів, коли позивач вимагає примусового здійснення обов'язку боржника-відповідача. Характерною особливістю позовів про присудження є те, що після їх розгляду й ухвалення за ними рішення, якщо вони добровільно не виконуються, ці рішення можуть бути виконані у примусовому порядку [4, с. 520]. Натомість позови про визнання - це позови, у яких позивач просить суд підтвердити наявність (позитивний позов про визнання) чи відсутність (негативний позов про визнання) між ним та відповідачем певних правовідносин. У такому разі рішення за такими позовами не потребують примусового виконання, адже захист права здійснюється безпосередньо рішенням суду [4, с. 52].
Перегляд судових рішень за виключними обставинами 3 підстави, передбаченої в п. 1 ч. 3 ст. 423 ЦПК, може бути здійснений виключно тоді, коли рішення суду ще не виконане. Зі змісту статті очевидно, що йдеться про неможливість застосування зазначеної підстави в ситуації, коли мало місце добровільне або примусове виконання судових рішень у справах за позовами про присудження, адже термінологія ЦПК використовує поняття «виконання судового рішення» як тотожне поняттю «примусове виконання судового рішення», що може мати місце виключно за результатами розгляду вимог про присудження (ч. 2 ст. 149 , ст. 157 , ч. 3 ст. 160 , ст. ст. 208 , 265,267, p. VI «Процесуальні питання, пов’ язані з виконанням судових рішень у цивільних справах та рішень інших органів (посадових осіб)» (ст. ст. 430-446), р. VII «Судовий контроль за виконанням судових рішень» (ст. ст. 447-453).

Проте зміст п. 1 ч. 3 ст. 423 ЦПК жодним чином не вказує на те, що перегляд справи за виключними обставинами 3 підстави, передбаченої відповідною нормою, можливий виключно у справах за позовами про присудження. У цьому контексті варто звернути увагу на телеологічне тлумачення відповідної норми. Вбачається, що її мета полягає в забезпеченні особі ефективного захисту їі прав та свобод у разі визнання закону, що був застосований в її справі, неконституційним. У цьому разі до уваги має бути взятий принцип правової визначеності, зокрема такий його аспект, як правило res judicata. Так, Свропейський суд з прав людини (далі - ЄСПЛ) у своїх рішеннях неодноразово зазначав, що право на справедливий судовий розгляд, гарантоване п. 1 ст. 6 Свропейської конвенції з прав людини, повинно тлумачитися у світлі Преамбули до Конвенції про захист прав людини й основоположних свобод 1950 р. (далі - ЄКПЛ), яка проголошує верховенство права частиною спільної спадщини договірних держав. Одним з основних аспектів верховенства права є принцип правової визначеності, який передбачає, серед іншого, що ухвалене судами остаточне рішення не може ставитися під сумнів [5]. Правова визначеність передбачає повагу до принципу res judicata, що є принципом остаточності судових рішень. Він, зокрема, означає, що жодна зі сторін не має права вимагати перегляду остаточного й обов'язкового судового рішення лише з метою проведення повторного слухання справи й ухвалення нового рішення. Повноваження судів вищої інстанції щодо перегляду справ мають використовуватися для виправлення судових помилок та помилок під час здійснення правосуддя, а не для проведення нового розгляду справи. Перегляд справи не може розглядатися як замаскована апеляція, а сама лише можливість існування двох поглядів на одне питання не є підставою для повторного розгляду 
справи. Відхилення від цього принципу можливе лише тоді, коли воно спричинене незалежними і непереборним обставинами [6]. Отже, відповідно до зазначеного принципу, ЄСПЛ залишає на розсуд національного законодавця визначення конкретних видів перегляду судових рішень, які набрали чинності, та підстав такого перегляду. Водночас мають бути забезпечені певні гарантії для дотримання балансу приватних і публічних інтересів під час відправлення правосуддя, зокрема, підстави для перегляду мають бути істотними та мають бути сформульовані досить чітко, щоб не допускати двоякого тлумачення, підстави для різних видів переглядів не повинні дублюватися, строки такого перегляду мають бути обмеженими та чітко регламентованими в законодавстві тощо.

Аналіз норм вітчизняного законодавства дозволяє констатувати необхідність наявності трьох умов для перегляду справи за виключними обставинами за п. 1 ч. 3 ст. 423 ЦПК, зокрема: а) встановлення неконституційності закону, іншого правового акта чи їхнього окремого положення; б) визнаний неконституційним закон, інший правовий акт мав бути застосований під час винесення рішення, яке переглядається за виключними обставинами; в) рішення суду у справі ще не виконано. Зазначене підтверджується i судовою практикою [3]. Водночас ніщо у змісті відповідної статті не свідчить про неможливість їі застосування у справах, де ухвалені рішення за вимогами про визнання або про перетворення, що не вимагають примусового виконання. Мета третьої умови вбачається в тому, щоб забезпечити певний рівень стабільності та правової визначеності суспільних відносин з огляду на досить тривалий строк, протягом якого можливий зазначений вид перегляду. Так, заява про перегляд за виключними обставинами із вказаної підстави має бути подана протягом тридцяти днів із дня офіційного оприлюднення відповідного рішення Конституційного Суду України, однак не пізніше десяти років із дня набрання судовим рішенням чинності (п. 4 ч. 1 , п. 2 ч. 2 ст. 424 ЦПК). Як видно, вказаним обмеженням законодавець унеможливлює застосування повороту виконання в ситуаціях, коли справа переглядатиметься за виключними обставинами через значний проміжок часу. Загалом уведення цього обмеження є виправданим для позовів про присудження, проте очевидно, що стосовно позовів про визнання та перетворювальних позовів таких ускладнень із поворотом виконання бути не може, отже, відсутні легітимні підстави для виключення рішень за вказаними позовами з об'єктів перегляду за виключними обставинами.

Зважаючи на вищенаведене, зазначене положення законодавства має тлумачитися таким чином, що коли рішення суду передбачає примусове виконання, то перегляд можливий, якщо рішення не виконане. Якщо ж рішення не потребує примусового виконання, то зазначена умова взагалі не застосовується за замовчуванням, адже рішення за позовами про визнання та про перетворення за своєю природою не передбачають такого виконання. Проте це не означає, що такі рішення не можуть бути об’єктами перегляду за виключними обставинами.

Крім того, варто звернути увагу на те, що момент виконання судового рішення як строк для виконання певних процесуальних дій згадується і в інших статтях ЦПК. Так, відповідно до ч. 2 ст. 270 ЦПК, заяву про ухвалення додаткового рішення може бути подано до закінчення строку на виконання рішення. Проте це не означає, що у справах, де ухвалені рішення за позовами про визнання або перетворення, які не можуть бути примусово виконані, отже, і не мають строку на виконання, неможутьбути ухвалені додатковірішення.

Нарешті, виключення з об'єктів оскарження за вказаною підставою рішень за позовами про визнання та перетворення значно б звузило гарантії, які мають бути забезпечені особі за результатами розгляду iï конституційної скарги, якщо закон, застосований в її справі, був визнаний неконституційним. Зокрема, особа не могла б скористатися переглядом за виключними обставинами з підстави, передбаченої в п. 1 ч. 3 ст. 423 ЦПК, якщо рішення в її справі не підлягало б за своєю природою примусовому виконанню, що також нівелює та робить декларативною можливість відновлення прав, свобод та інтересів такої особи після використання механізму конституційної скарги.

Отже, процесуальне законодавство прямо передбачає можливість перегляду судових рішень за виключними обставинами з підстав ухвалення рішення Конституційного Суду України щодо неконституційності закону, який був застосований у справі, що має на меті забезпечення реального, а не ілюзорного механізму захисту прав та інтересів учасників справи, що, однак, не суперечить загальному правилу про момент втрати чинності положеннями нормативного акта за визнання його неконституційним рішенням Конституційного Суду України. Протилежне тлумачення призводило б до неможливості застосування зазначеної підстави для перегляду за виключними обставинами, адже на момент розгляду справи судом застосовні положення законодавства завжди є чинними та конституційними, адже ще не стали предметом перевірки на конституційність у Конституційному Суді України. Крім того, п. 1 ч. 3 ст. 423 ЦПК жодним чином не вказує на те, що перегляд справи за виключними обставинами з підстави, передбаченої відповідною нормою, можливий виключно у справах за позовами про присудження, адже виключення з об’єктів оскарження за вказаною підставою рішень за позовами про визнання та пе- 
ретворення значно б звузило гарантії, які мають бути забезпечені особі за результатами розгляду їі конституційної скарги, якщо закон, застосований в іiї справі, був визнаний неконституційним, що також нівелює та робить декларативною можливість захисту прав, свобод та інтересів такої особи.

\section{Jimepamypa}

1. Постанова Верховного Суду у складі колегії суддів Першої судової палати Касаційного цивільного суду від 13 листопада 2019 p. URL: http://reyestr.court.gov.ua/ Review/86173768.

2. Ухвала Східного апеляційного господарського суду від 8 серпня 2019 p. URL: http://reyestr.court.gov. ua/Review/ 83565750.

3. Постанова Касаційного господарського суду від 20 червня 2019 p. URL: http://reyestr.court.gov.ua/ Review/ 82599567.

4. Курс цивільного процесу / за заг. ред. проф. В.В. Комарова. Харків : Право, 2011. $1351 \mathrm{c.}$

5. Brumarescu v. Romania, № 28342/95, par. 61, 28 October 1999. URL: https://hudoc.echr.coe.int/ eng\#\{"itemid": ["001-58337"]\}.

6. Ryabykh v. Russia, № 52854/99, par. 51. URL: http://www.echr.ru/documents/doc/new/003.htm.

\section{Анотація}

Цувіна $T$. А. Інститут конституційної скарги та перегляд судових рішень за виключними обставинами в контексті принципу верховенства права. - Стаття.

У статті аналізуються проблемні питання, які виникають під час перегляду судових рішень за виключними обставинами 3 підстав встановлення Конституційним Судом України неконституційності (конституційності) закону, іншого правового акта чи їхнього окремого положення, застосованого (не застосованого) судом під час вирішення справи, якщо рішення суду ще не виконане (пункт 1 частини 3 статті 423 Цивільного процесуального кодексу України).

На основі аналізу практики Верховного Суду робиться висновок щодо відсутності єдності підходів у застосуванні відповідного виду перегляду в різних видах судочинства. Обгрунтовується необхідність можливості перегляду судових рішень за виключними обставинами в разі визнання судових рішень неконституційним за наслідками розгляду конституційної скарги, незважаючи на законодавче положення про відсутність ретроспективної дії рішень Конституційного Суду України, адже протилежний підхід робить судовий захист прав осіб ілюзорним і суперечить міжнародним стандартам справедливості правосуддя відповідно до п. 1 ст. 6 Конвенції про захист прав людини та основоположних свобод 1950 року, що є невід'ємною складовою частиною принципу верховенства права в демократичному суспільстві. Робиться висновок про іманентний зв'язок між розглядом конституційної скарги особи та подальшим переглядом справи за виключними обставинами, що дозволяє реалізувати її право на судовий захист повною мірою.
Автором наводяться аргументи проти вузького тлумачення сфери застосування пункту 1 частини 3 статті 423 Цивільного процесуального кодексу України як такої, що застосовується виключно до рішень про присудження, яке трапляється у практиці національних судів. Натомість обгрунтовується необхідність поширення відповідної норми і на рішення за позовами про визнання та перетворювальними позовами, адже вузький підхід до тлумачення сфери застосування відповідної норми призводить до необгрунтованого звуження прав учасників справи.

Ключові слова: перегляд справи за виключними обставинами, конституційна скарга, верховенство права, право на справедливий судовий розгляд.

\section{Summary}

Tsuvina T. A. Constitutional complaint and review on exceptional circumstances in terms of the rule of law. - Article.

The article is devoted to the issues arising during the review of court decisions in exceptional circumstances on the grounds of establishing by the Constitutional Court of Ukraine the unconstitutionality (constitutionality) of the law, another legal act or their separate provision applied (not applied) by the court in the decision of the case, if the court decision has not been executed (subpart. 1, para. 1, Article 423 Civil Procedure Code of Ukraine).

Based on the analysis of the case law of the Supreme Court, it is concluded that there is a lack of uniformity of approaches in the application of procedural provisions during this review in different types of judicial proceedings (civil, commercial, administrative). The necessity of the possibility of reviewing court decisions on exceptional circumstances in the case of recognition of legal provisions unconstitutional as a result of a constitutional complaint, is justified, despite the legislative provision on the absence of retrospective effect of decisions of the Constitutional Court of Ukraine. Since the opposite approach renders the judicial protection illusory and violates the international guaranties of the right to a fair trial according to para. 1 Article 6 of the Convention on the Protection of Human Rights and Fundamental Freedoms, which is an integral part of the rule of law in a democratic society. It is concluded that there is an immanent link between the consideration of a person's constitutional complaint and the subsequent review of the case in exceptional circumstances, enabling person to use his or he right to judicial protection.

The author argues against a narrow interpretation of the scope of subpar 1 para 3 Article 423 of the Civil Procedural Code as being applicable exclusively to award decisions found in the practice of national courts. Instead, the author justifies the need to extend the relevant rule and to decide on claims for recognition and transformative claims, because a narrow approach to interpreting the scope of the relevant rule leads to an unjustified narrowing of the parties' rights.

Key words: review on exceptional circumstances, constitutional complaint, rule of law, right to fair trial. 